\title{
Cyclic enkephalin-deltorphin hybrids containing a carbonyl bridge: structure and opioid activity
}

\author{
Małgorzata Ciszewska1, Katarzyna Ruszczyńska², Marta Oleszczuk³, Nga N. Chung ${ }^{4}$, \\ Ewa Witkowska', Peter W. Schiller ${ }^{4}$, Jacek Wójcik ${ }^{2}$ and Jan Izdebski ${ }^{1 凶}$
}

'Peptide Laboratory, Department of Chemistry, University of Warsaw, Warszawa, Poland; 2Laboratory of Biological NMR, Institute of Biochemistry and Biophysics, Polish Academy of Sciences, Warzsawa, Poland; ' ${ }^{D}$ epartment of Biochemistry, University of Alberta, Edmonton, Alberta, Canada; ${ }^{4}$ Laboratory of Chemical Biology and Peptide Research, Clinical Research Institute of Montreal, Quebec H2W IR7, Canada

\begin{abstract}
Six hybrid $\mathrm{N}$-ureidoethylamides of octapeptides in which an N-terminal cyclic structure related to enkephalin was elongated by a C-terminal fragment of deltorphin were synthesized on MBHA resin. The synthetic procedure involved deprotection of Boc groups with $\mathrm{HCl} /$ dioxane and cleavage of the peptide resin with $45 \%$ TFA in DCM. DLys and D-Orn were incorporated in position 2, and Lys, Orn, Dab, or Dap in position 5. The side chains of the dibasic amino function were protected with the Fmoc group. This protection was removed by treatment with $55 \%$ piperidine in DMF, and cyclization was achieved by treatment with bis-(4-nitrophenyl)carbonate. Using various combinations of dibasic amino acids, peptides containing a 17-, 18-, 19- or 20-membered ring structure were obtained. The peptides were tested in the guinea-pig ileum (GPI) and mouse vas deferens (MVD) assays. Diverse opioid activities were observed, depending on the size of the ring. Extension of the enkephalin sequence at the C-terminus by a deltorphin fragment resulted in a change of receptor selectivity in favor of the $\delta$ receptor. The conformational propensities of selected peptides were determined using the EDMC method in conjunction with data derived from NMR experiments carried out in water. This approach allowed proper examination of the dynamical behavior of these small peptides. The results were compared with those obtained earlier with corresponding $\mathrm{N}$-(ureidoethyl)pentapeptide amides.
\end{abstract}

Keywords: cyclic opioid peptides, conformation, NMR, $\mathrm{N}$-(ureidoethyl)amides, side-chain to side-chain cyclization; structure-activity relationship

Received: 06 December, 2010, revised: 24 March, 2011; accepted: 08 May, 2011; available on-line: 17 May, 2011

\section{INTRODUCTION}

Endogenous opioid peptides, such as enkephalins, endorphins, deltorphins, dynorphins and endomorphins are involved in regulation of many biological processes, among them pain control. However, clinical utility as therapeutic analgesics is limited by their susceptibility to enzymatic degradation and several side effects. Biological activities of opioid peptides are mediated through three major opioid receptor types $(\mu, \delta$ and $x$ ) and the distinct structure of a peptide has an impact on the selectivity of receptor types and consequently on the activity profile.

The analgesic effect of the most effective therapeutic non-peptidic agent, morphine, is mediated through the $\mu$ opiate receptor. However, its clinical utility is limited by the side effects, such as respiratory depression and development of tolerance and dependence.

Enkephalins and other $\delta$ opiate receptor selective drugs share the morphin's analgesic effect, but have reduced negative properties: respiratory depression (Cheng et al., 1993; Su et al., 1998) and reveal minimal potential for the development of physical dependence (Cowan et al., 1988).

The development of new opioid peptides with increased selectivity for $\delta$ opioid receptor seems to be a good avenue to obtaining drugs that may produce only desired physiological responses. One of the methods that could allow reaching this goal is the design of conformationally restricted peptides. The most promising approach to obtaining a selective agonist is cyclization of a linear active peptide which can adopt a conformation able to interact preferentially with one receptor. This is also expected to increase the enzymatic stability and activity of the resulting cyclic peptide.

Peptides can be cyclized through formation of additional bonds, e.g., disulfide, lactone, lactame or formation of bridges between two amino-acid residues, e.g., a carbonyl bridge or oligomethylene group (Davis, 2003; Janecka \& Kruszynski, 2005). In several cases incorporation of cyclized opioid peptides has been shown to enhance selectivity for a distinct opioid receptor type. Further increase in selectivity of an active and selective cyclic peptide is also possible as demonstrated by replacement of cysteine by $\beta, \beta$-dimethylcysteine in an enkephalin analog cyclized by formation of a disulfide bridge (Akiyama et al., 1985).

Attempts to increase selectivity of a cyclic peptide by synthesis of chimeric peptides have also been reported: -Val-Gly- $\mathrm{NH}_{2}$, which is a C-terminal fragment of deltorphin address sequence (-Val-Val-Gly- $\mathrm{NH}_{2}$ ), was added to the above-mentioned enkephalin analogs cyclized by formation of a disulfide bridge between two $\beta, \beta-$ dimethylcysteine residues (Misicka et al., 1994).

Previously we described the synthesis, biological activity, and conformational analysis of several highly potent side-chain-to-side-chain cyclized analogs of enkephalin

e-mail: izdebski@chem.uw.edu.pl

Abbreviations: CLUST, a program for cluster analysis; EDMC, electrostatically driven monte carlo; gHSQC, gradient heteronuclear single quantum coherence spectroscopy; MBHA, 4-methylbenzhydrylamine; MORASS, multiple overhauser relaxation analysis and simulation; ROESY, rotating frame overhauser enhancement spec troscopy; R.m.s.d., Root mean square deviation 
amides (H-Tyr-Gly-Gly-Phe-Met- $\mathrm{NH}_{2}$ ) in which Gly ${ }^{2}$ and $\mathrm{Met}^{5}$ were replaced by dibasic amino acids and cyclic structure was obtained by incorporation of side-chain amino groups into urea residue (Pawlak et al., 2001; Filip et al., 2005). Using the same synthetic procedure we obtained analogs of an $\mathrm{N}$-terminal segment of deltorphin (H-Tyr-Gly-Phe-Asp-) by introduction of dibasic amino acids in positions 2 and 4 (Filip et al., 2003). We also obtained $N$-(ureidoethyl)amides of enkephalin related to the cyclic amides studied earlier, using a convenient synthetic method developed in this laboratory (Ciszewska et al., 2009).

Most peptides of those three series showed very high potency both in the guinea-pig ileum (GPI) and mouse vas deferens (MVD) assays, which indicated a need to modify their structure to obtain more selective opiates. Addition of an address sequence of deltorphin (-Val-ValGly- $\mathrm{NH}_{2}$ ) to the cyclic structure comprising positions $1-4$ resulted in greatly increased $\delta$ selectivity. Several such peptides were a hundred times more active in the MVD assay than in the GPI assay (Zieleniak et al., 2008).

In this work we obtained six hybrid peptides containing a message sequence of enkephalin, restricted via a urea bridge as described above, and a C-terminal address of deltorphin. To facilitate the synthesis, the peptides were obtained in the form of $N$-(ureidoethyl)amides.

\section{MATERIALS AND METHODS}

Peptide synthesis. General procedure. The p-nitrophenoxycarbonyl derivative of Boc-diaminoethane was obtained as described earlier (Wiszniewska et al., 2005). This compound $(0.401 \mathrm{~g}, 1.25 \mathrm{mmol})$ was coupled to the MBHA resin (0.25 meq/g, 1\% crosslink, 100-200 mesh) in DMF at $60^{\circ} \mathrm{C}$ for 48 days. The Boc group was removed by treatment with $15 \% \mathrm{HCl} /$ dioxane, then Boc- amino acids were successively attached using $N, N$-diisopropylcarbodiimide as a coupling reagent and $15 \% \mathrm{HCl} /$ dioxane for deprotection. The side chain amino function was protected by Fmoc group. The Tyr side chain was not protected. The peptidyl-resin was treated with $55 \%$ piperidine in DMF with stirring for $50 \mathrm{~min}$ to remove the Fmoc groups and washed with DMF. To a stirred suspension of peptidyl-resin in DMF (200 $\mathrm{ml})$ bis( $\not$-nitrophenyl)carbonate $(0.76 \mathrm{~g}, 0.25 \mathrm{mmol})$ was added in portions (about $50 \%+25 \%+12.5 \%+12.5 \%$ ) and stirring was continued for 7 days. DIPEA (0.065 g) was gradually added during this reaction. The peptide was cleaved off by treatment with 55\% TFA/DCM for $1+20 \mathrm{~min}$. TFA was evaporated under reduced pressure and the residue was lyophilized. The yield of the crude product was $80-140 \mathrm{mg}$. The products were purified by semi-preparative reversed-phase high performance liquid chromatography using the solvent system: A: $0.05 \%$ TFA in water, B: $60 \% \mathrm{MeCN}$ in A on a Vydac column (Nucleosil $300, C_{18}, 5 \mu \mathrm{m}, 10 \times 250 \mathrm{~mm}$ ), flow rate of 2 $\mathrm{ml} / \mathrm{min}$, gradient $\mathrm{B}(15 \%$ in $15 \mathrm{~min}, 15-30 \%$ in $15 \mathrm{~min}$, $30-45 \%$ in $40 \mathrm{~min})$. Fractions were analyzed on a Vertex Nucleosil-100 $\mathrm{C}_{18}$ column $(4 \mathrm{~mm} \times 250 \mathrm{~mm}, 5 \mu \mathrm{m})$, flow rate $1 \mathrm{ml} / \mathrm{min}$. For analysis, a linear gradient of $20-80 \%$ $B$ was used $(1 \mathrm{ml} / \mathrm{min}, \mathrm{t}=15 \mathrm{~min})$, detection at $220 \mathrm{~nm}$. Fractions were pooled for maximum purity rather than yield. Homogeneous fractions containing one peak were combined and lyophilized. Structures were confirmed by ESI-MS mass spectrometry (Finningan MAT 95S spectrometer, Bremen, Germany). 1: M calcd. 965.5, obtained 988.6 $\left(\mathrm{M}+\mathrm{Na}^{+}\right) ; 2$ : $\mathrm{M}$ calcld. 979.5, obtained 1002.6
$\left(\mathrm{M}+\mathrm{Na}^{+}\right) ; 3: \mathrm{M}$ calcld 993.4, obtained $1016.6\left(\mathrm{M}+\mathrm{Na}^{+}\right)$; 4: $\mathrm{M}$ calcld. 951.3, obtained $974.5\left(\mathrm{M}+\mathrm{Na}^{+}\right)$; 5: $\mathrm{M}$ calcld. 965.5, obtained $988.6\left(\mathrm{M}+\mathrm{Na}^{+}\right)$; 6: $\mathrm{M}$ calcd. 993.4 obtained $1016.4\left(\mathrm{M}+\mathrm{Na}^{+}\right)$. The structures of the peptides are presented in Fig. 1.

Bioassays. The guinea-pig ileum (GPI) assay ( $\mu$ receptor-representative) (Paton, 1957) and the mouse vas deferens (MVD) assay ( $\delta$ receptor-representative) (Henderson et al., 1972) were carried out as reported in detail elsewhere (Schiller et al., 1978; DiMaio \& Schiller, 1980). A log dose-response curve was determined with $\left[\mathrm{Leu}^{5}\right]$-enkephalin as a standard for each ileum and vas preparation and the $\mathrm{IC}_{50}$ values of the compounds being tested were normalized according to a published procedure (Waterfield et al., 1979). The results are presented in Table 1.

NMR spectroscopy and theoretical analysis. The methodology used for generation and selection of conformations was previously described for oxytocin and arginine-vasopressin (Liwo et al., 1996). It was applied by us to one of the opioid peptides and described in details in this journal (Sidor et al., 1999) and by others to a number of compounds (Cohen et al., 2002; Masman et al., 2006; 2008). Subsequently we used this methodology with success in several studies of different opioid analogs (Pawlak et al., 2001; Filip et al., 2003; 2005; Ciszewska et al., 2009). In this paper NMR spectra of peptides 2, 3 and 4, which were sufficiently soluble in water, were recorded on a Varian INOVA $400 \mathrm{MHz}$ and/or a Varian Unity PLUS $500 \mathrm{MHz}$ spectrometer at $25^{\circ} \mathrm{C}$ in $\mathrm{H}_{2} \mathrm{O} / \mathrm{D}_{2} \mathrm{O}(9: 1, \mathrm{v} / \mathrm{v})$. For $1 \mathrm{D}$ proton spectra $16 \mathrm{k}$ points were collected and a spectral width of $6 \mathrm{kHz}$ was used. $2 \mathrm{D}$ experiments were measured collecting $2 \mathrm{k}$ points using $4.5 \mathrm{kHz}$ spectral width in the proton direction and 256-point increments in the F1 direction. The same spectral width was applied in the F1 direction in homo-nuclear $2 \mathrm{D}$ spectra, whereas a width of $25 \mathrm{kHz}$ and $2 \mathrm{kHz}$ for carbon and for nitrogen, respectively, was used for hetero-nuclear correlations. A mixing time of $0.08 \mathrm{~s}$ was used in TOCSY measurements and $0.25 \mathrm{~s}$ in ROESY experiments. DSS was used as a reference external standard for proton, carbon and nitrogen dimensions (Wishart et al., 1995). Chemical shifts were assigned using TOCSY, COSY, HSQC $\left[{ }^{15} \mathrm{~N},{ }^{1} \mathrm{H}\right]$, and HSQC $\left[{ }^{13} \mathrm{C}\right.$, $\left.{ }^{1} \mathrm{H}\right]$ techniques (Aue et al., 1976; Braunschweiler \& Ernst, 1983; Bothner-By et al., 1984; Bax \& Davis, 1985; Bax \& Freeman, 1985; Palmer III et. al., 1991; Kay et al., 1992) and they are available in Supplementary Materials at www.actabp.pl (Table $1 \mathrm{~S}$ and $2 \mathrm{~S}$ ). ${ }^{3} J_{\mathrm{H \alpha HN}}$ couplings were obtained from 1D ${ }^{1} \mathrm{H}$ spectra and temperature coefficients were determined with $1 \mathrm{D}{ }^{1} \mathrm{H}$ spectra recorded at: $6.8,11.0,15.5,19.1$ and $25.0^{\circ} \mathrm{C}$ (see Table $3 \mathrm{~S}$ in Supplementary Materials). Cross-peak volume calculations were done with the SPARKY program (www.cgl.ucsf.edu/ home/sparky) using data from the ROESY spectra and are available in Supplementary Materials (Tables 4S, 5S and $6 \mathrm{~S})$.

Structures of each peptide were calculated using the EDMC method described by (Liwo et al., 1996), e.g., for each peptide starting from a conformation with random geometry its energy was minimized with the ECEPP/3 force field (Nemethy et al., 1992) and surface model SFROPT (Vila et al., 1991). Thus, the total conformational energy included a sum of terms: electrostatic, nonbonding, hydrogen-bond, torsional and terms accounting for the entropy for loop closing and solvation. The $\phi$ and $\psi$ angels of the resulting geometry were further perturbed using the Monte Carlo method (Li \& Scheraga, 
1987) and after energy minimization the obtained conformation was compared with the previous one and accepted or discarded using a geometry and/or energy criterion. If the conformation was accepted the procedure was repeated.

The ensemble of resulting structures for each peptide was clustered into families using the program CLUST (Spath, 1980). Finally, theoretical NOESY spectra were generated for each family of structures with the program MORASS (Meadows, 1994) and statistical weights for each conformation were obtained by fitting a linear combination of generated spectra to the experimental data using the Marquardt method (Marquardt, 1963).

\section{RESULTS AND DISCUSSION}

The synthesis was performed using a method based on the observation that $N$-ureidoethyl units could be obtained in the synthesis on MBHA resin by reaction of the resin with p-nitrophenyl carbonate of Boc-ethylenediamine and that the aminoethylurea unit formed was stable during treatment with $\mathrm{HCl}$ /dioxane used for removal of the Boc group (Wiszniewska et al., 2005). D-Lys or D-Orn were incorporated in position 2, and Lys, Orn, Dab or Dap in position 5 of the peptide sequence using Boc-protected derivatives in the $\alpha$-amino group and Fmoc protection at the side chain amino group. After removal of the Fmoc group by treatment with $55 \%$ piperidine in DMF and cyclization in a reaction with bis-(4-nitrophenyl)carbonate the resulting peptide was cleaved from the resin by treatment with $45 \%$ TFA in DCM. The products were purified using semipreparative RP-HPLC. Higher amounts of side products in crude products were observed than for similar syntheses in which cyclization was performed in solution (Pawlak et al., 1997; Filip et al., 2003). The increased amount of side-products may be due to formation of a carbonyl bridge between two peptide chains. In cyclization in solution, this problem was overcome by strong dilution of the reaction mixture. Fortunately, using semi-preparative HPLC, we were able to isolate the desired products. All samples for biological studies and NMR measurements were free of any contamination, as judged from analytical HPLC and MS spectra. The chemical formulas of the peptides are presented in Fig. 1. In vitro opioid activity profiles of the peptides were determined using the GPI and MVD assays (Table 1). The peptides were found to be agonists in both assays. The activities of the peptides varied depending on the size of the ring. The most active was peptide 1 in which an 18-membered ring was

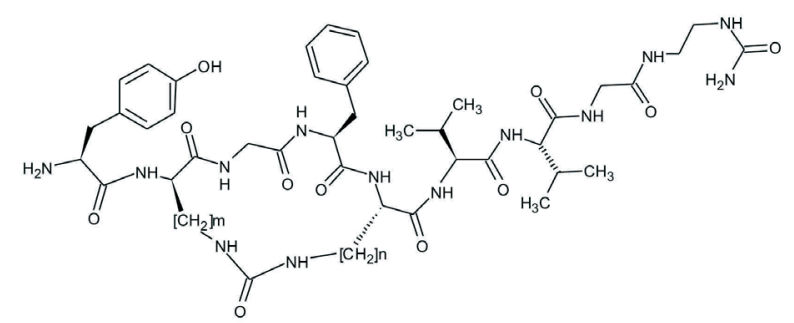

Figure 1. Structural formula of peptides:

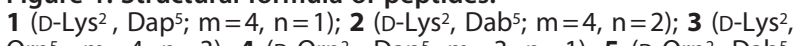
$\left.\mathrm{Orn}^{5} ; \mathrm{m}=4, \mathrm{n}=3\right) ; 4\left(\mathrm{D}-\mathrm{Orn}^{2}, \mathrm{Dap}^{5} ; \mathrm{m}=3, \mathrm{n}=1\right) ; \mathbf{5}\left(\mathrm{D}-\mathrm{Orn}^{2}, \mathrm{Dab}^{5}\right.$; $\mathrm{m}=3, \mathrm{n}=2) ; 6\left(D-O \mathrm{n}^{2}\right.$, Lys $\left.^{5} ; \mathrm{m}=3, \mathrm{n}=4\right)$

formed by incorporation of side-chain amino groups of D-Lys and Dap. It should be recalled that among amides of cyclic enkephalin the most active peptide contained the same ring (Pawlak et al., 2001). It can be seen that the activity of the peptides is high in the MVD assay and relatively lower in the GPI assay.

Since peptide 1 is the most $\delta$-selective agonist in this series and deserves to be studied in vivo, it is reasonable to compare (see Table 2) the selectivity of all peptides studied earlier containing the cyclic structure formed by incorporation of side chain amino groups of D-Lys and L-Dap: the GPI/MVD ratios of amide of $\operatorname{cyclo}\left[N^{\varepsilon}, N^{\delta}\right.$ -carbonyl-D-Lys ${ }^{2}$,Dap ${ }^{5}$ ]enkephalin and $N$-(ureidoethyl) amide of cyclo[ $\left[N^{\varepsilon}, N^{\delta}\right.$-carbonyl-D-Lys $\left.{ }^{2}, \mathrm{Dap}^{5}\right]$ enkephalin were 0.33 (Pawlak et al., 1997) and 1.09 (Ciszewska et al., $2009)$, respectively, and in the case of the hybrid peptide 1 it was 6.97. This shift in selectivity in favor of $\delta$ receptors seems to be important in view of our recent finding (Kotlińska et al., 2009) that even amide of $\operatorname{cyclo}\left[N^{\varepsilon}, N^{\delta}\right.$ -carbonyl-D-Lys ${ }^{2}$,Dap ${ }^{5}$ enkephalin, which is highly potent both in GPI and MVD assays, in vivo studies, with the use of selective opioid receptor antagonists, induced antinociception predominantly through opioid $\delta$ receptors.

These results clearly indicate that the increase of selectivity in favor of the $\delta$ receptor was achieved by a decrease in the affinity of these peptides for the $\mu$ receptor, whereas the $\delta$ receptor affinity was more or less unchanged. These results show that in this case the role of the address is different from what was expected on the basis of the message-address concept, insofar as addition of the address sequence did not increase the affinity for the $\delta$ receptor.

In our previous studies on deltorphin analogs we observed that elongation of the cyclic $\mathrm{N}$-terminal segment (Filip et al., 2003; Zieleniak et al., 2008) with Val-Val-Gly,

Table 1. GPI and MVD assays of cyclic hybrid peptides

\begin{tabular}{|c|c|c|c|c|c|c|c|c|}
\hline \multicolumn{3}{|c|}{ PEPTIDE } & \multicolumn{2}{|c|}{ GPI } & \multicolumn{2}{|c|}{ MVD } & \multicolumn{2}{|c|}{ GPI/MVD } \\
\hline No. & Ring size & D-Daa ${ }^{2}$ & $\mathrm{Daa}^{5}$ & $\mathrm{IC}_{50}[\mathrm{nM}]$ & Rel. potency & $\mathrm{IC}_{50}[\mathrm{nM}] \mathrm{a}$ & Rel. potency & $\mathrm{IC}_{50}$ ratio \\
\hline 1 & 18 & Lys & Dap & $12.9 \pm 1$ & $19.0 \pm 2$ & $1.85 \pm 0.1$ & $6.15 \pm 0.45$ & 6.97 \\
\hline 2 & 19 & Lys & Dab & $47.5 \pm 5$ & $5.18 \pm 0.5$ & $16.9 \pm 0.5$ & $0.675 \pm 0.019$ & 2.81 \\
\hline 3 & 20 & Lys & Orn & $30.8 \pm 1$ & $7.98 \pm 0.4$ & $4.18 \pm 5$ & $2.73 \pm 0.034$ & 7.37 \\
\hline 4 & 17 & Orn & Dap & $76.9 \pm 3$ & $3.20 \pm 0.1$ & $18.5 \pm 2$ & $0.617 \pm 0.058$ & 4.16 \\
\hline 5 & 18 & Orn & Dab & $72.1 \pm 6$ & $3.41 \pm 0.3$ & $20.5 \pm 4$ & $0.555 \pm 0.109$ & 3.52 \\
\hline 6 & 20 & Orn & Lys & $71.3 \pm 3$ & $3.45 \pm 0.2$ & $14.5 \pm 1$ & $0.788 \pm 0.078$ & 4.92 \\
\hline \multicolumn{4}{|c|}{ [Leu5]enkephalin } & $246 \pm 39$ & 1 & $11.4 \pm 1.1$ & 1 & 21.6 \\
\hline
\end{tabular}

${ }^{a}$ Mean of 3-6 determinations \pm S.E.M. 
Table 2. GPI/MVD ratio of enkephalin $\mathrm{N}$-(ureidoethyl)amides (Ciszewska et al., 2009) and enkephalin/deltorphin hybrid $\mathrm{N}$ (ureidoethyl)amides (this work)

\begin{tabular}{lll}
\hline $\begin{array}{l}\text { Amino acids in } \\
\text { positions } 2 \text { and } 4\end{array}$ & $\begin{array}{l}\text { Enkephalin ureido- } \\
\text { ethylamides }\end{array}$ & $\begin{array}{l}\text { Enkephalin/deltorphin } \\
\text { hybrid ureidoethyl- } \\
\text { amides }\end{array}$ \\
\hline D-Lys, Dap & $1.97 / 1.81(=1.09)$ & $\begin{array}{l}12.9 / 1.85(=6.97) \\
47.5 / 16.9(=2.81)\end{array}$ \\
D-Lys, Dab & $5.55 / 6.00(=0.92)$ & $\begin{array}{l}30.8 / 4.18(=7.36) \\
\text { D-Lys, Orn }\end{array}$ \\
D-Orn, Dap & $18.1 / 22.7(=0.79)$ & $76.9 / 18.5(=4.16)$ \\
D-Orn, Dab & $3.36 / 11.6(=0.29)$ & $72.1 / 20.5(=3.53)$ \\
D-Orn, Lys & $16.1 / 28.2(=0.57)$ & $71.3 / 14.5(=4.92)$ \\
\hline Mean value & $9.40 / 14.1(=0.64)$ & $51.9 / 12.6(=4.12)$ \\
\hline
\end{tabular}

to obtain the full sequence of deltorphin, also resulted in an increase in selectivity in favor of the $\delta$ receptor. This was not only due to a decrease in activity at the $\mu$ receptor but also to an increase of the activity at the $\delta$ receptor.

It seems that at least in the cases presented in this work, the use of the term modulator rather than the commonly used term address may be more appropriate for the description of a peptide segment which upon addition to a biologically active peptide changes the receptor selectivity.

For a better description and understanding of the biological results at the molecular level the NMR/EDMC method was employed (Sidor et al., 1999). Temperature coefficients of amide protons obtained from NMR spectra of peptides 2,3 and 4 are rather high (Table 3S). Relatively lower values were observed only for amide protons of the $\mathrm{Daa}^{5}$ residues, similar to what was observed for other opioid peptide analogs (Ciszewska et al., 2009; Zieleniak et al., 2008). This suggests that the amide protons are not engaged in intramolecular hydrogen bonding.

The ensembles of conformations generated and accepted in the EDMC procedure for each peptide are listed in Table $7 \mathrm{~S}$ in Supplementary Materials. They were clustered into families using an energy threshold of $20 \mathrm{kcal} / \mathrm{mol}$ and an r.m.s.d. of $0.15 \AA$ as separation criteria. Numbers of the families are also given in Table 7S. For representatives of each family, NOESY spectra were generated assuming a mixing time of 0.2 $\mathrm{s}$ and applying a correlation time of 0.45 ns. The Marquardt convergence criterion value of $10^{-5}$ was used in calculations of statistical weights of conformations. The conformers obtained for peptides 2,3 and 4 using the EDMC/NMR method are presented as their VMD (Humphrey et al., 1996) drawings in Fig. 2 and corresponding selected torsional angles are listed in Table 3.

Inspection of the data presented in Table 3 reveals a large diversity of conformations of the peptides. Their geometries and populations differ significantly. In each case several well populated conformers with substantially varying distances between the aromatic rings of $\mathrm{Phe}^{1}$ and $\mathrm{Tyr}^{4}$ were calculated.

A comparison of the r.m.s.d. values calculated for conformers of these peptides and those obtained earlier for their shorter analogs (Ciszewska et al., 2009) indicates that the flexibility of the main rings is similar. The r.m.s.d. values were calculated using the carbon and nitrogen atoms of the main ring for 2,3 and 4 ,
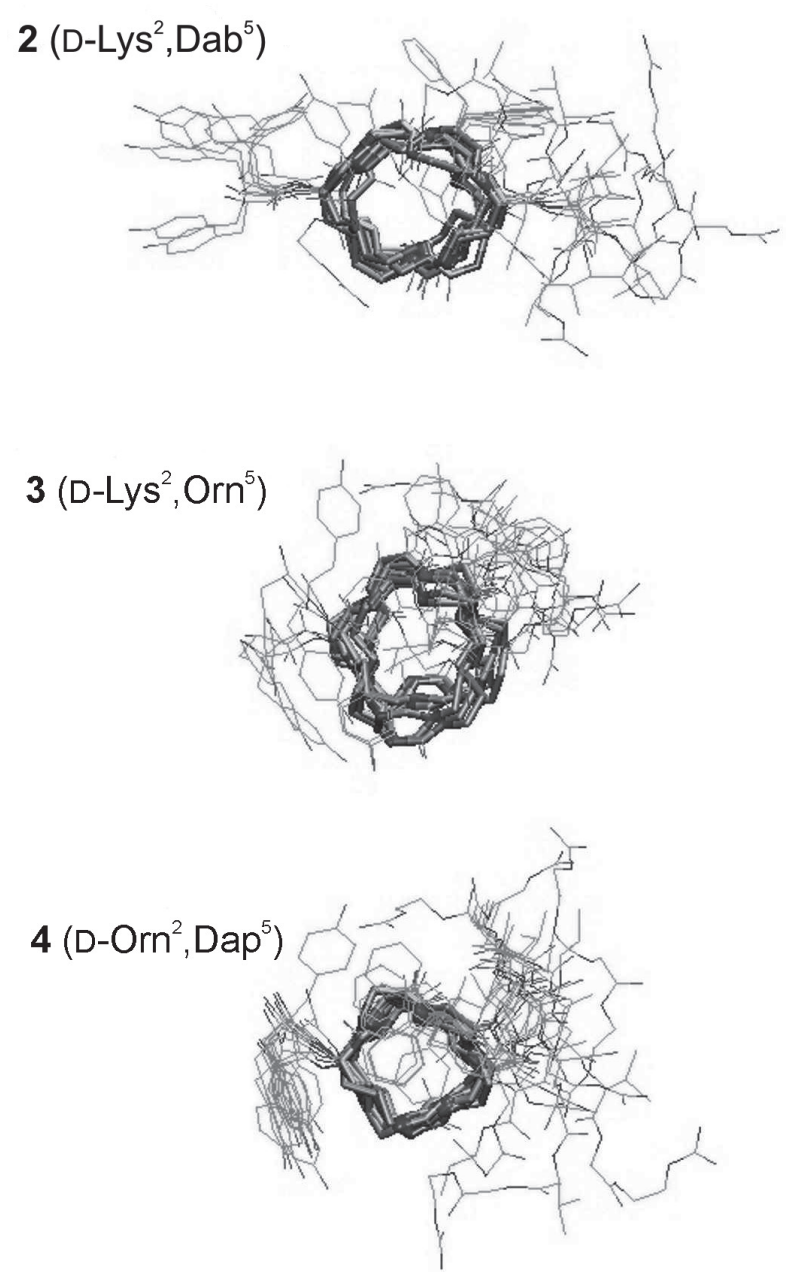

Figure 2. VMD drawings (Humphrey et al., 1996) of the most populated (above $3 \%$ ) EDMC/NMR calculated conformations of peptides 2, 3 and 4

The structures are superimposed using $\mathrm{C}$ and $\mathrm{N}$ atoms of the main ring

yielding values of $0.68 \AA, 0.80 \AA$ and $0.46 \AA$, respectively, while the r.m.s.d. values reported for the shorter analogs were $0.75 \AA, 0.74 \AA$ and $0.51 \AA$, respectively. The r.m.s.d. values calculated after superposition in the peptide segment situated between the Tyr and Phe residues were 0.40 for $2,0.45$ for 3 and $0.27 \AA$ for 4 , which suggests decreased conformational diversity as compared with the whole ring. This propensity of the main ring is common for all types of the peptides analyzed by us earlier (Pawlak et al., 2001; Filip et al., 2005; Ciszewska et al., 2009).

The r.m.s.d. values calculated using all heavy atoms of all residues were 3.73 for $2,2.73$ for 3 and $2.83 \AA$ for 4 , which indicates a rather high conformational freedom of these peptides. This opens the possibility for additional intramolecular interactions. In fact, for all three peptides NOE contacts were observed between the ring protons of $\mathrm{Phe}^{4}$ and the $\mathrm{CH}_{3}$ groups of $\mathrm{Val}^{6}$. In addition, visual inspection of the VMD drawings of all calculated conformers shown in Fig. 2 reveals that the conformers of peptide 3 are relatively compact. This is in agreement with the NOE contacts between $\gamma \mathrm{CH}_{3}\left(\mathrm{Val}^{7}\right)$ and ring $\left(\mathrm{Tyr}^{1}\right)$ protons observed in the spectra of this peptide. It may also be noticed that for a large set of conformers of peptide 4 their C- 
Table 3. Parameters for the most populated (populations above $3 \%$ ) conformations of peptides 2,3 and 4 found in water

\begin{tabular}{|c|c|c|c|c|c|c|c|c|c|c|c|}
\hline & $\chi_{1}(1)^{\mathrm{a}}$ & $\psi(1)^{\mathrm{a}}$ & $\varphi(2)^{\mathrm{a}}$ & $\psi(2)^{\mathrm{a}}$ & ${ }^{\mathrm{a}} \varphi(3)^{\mathrm{a}}$ & a $\psi(3)$ & )$^{\mathrm{a}} \varphi(4)^{\mathrm{a}}$ & a $\quad \chi_{1}(4)^{\mathrm{a}}$ & $\mathrm{r}^{\mathrm{b}}$ & $\mathrm{E}^{\mathrm{c}}$ & pop $^{\mathrm{d}}$ \\
\hline \multicolumn{12}{|c|}{$2\left(\mathrm{D}-\mathrm{Lys}^{2}, \mathrm{Dab}^{5}\right)$} \\
\hline $2-1$ & -67 & -39 & 148 & -135 & 158 & -163 & -99 & -61 & 12.6 & 0.0 & 22.4 \\
\hline $2-2$ & -64 & 151 & 151 & -133 & 136 & -112 & -153 & 172 & 17.4 & -0.5 & 19.7 \\
\hline $2-3$ & 170 & -58 & 148 & -136 & 173 & 172 & -86 & -57 & 7.5 & -0.7 & 14.3 \\
\hline $2-4$ & -66 & -36 & 148 & -132 & 136 & -113 & -152 & 174 & 16.7 & 0.7 & 9.1 \\
\hline $2-5$ & 171 & -51 & 135 & -88 & -76 & 72 & -162 & 166 & 7.2 & 1.1 & 6.0 \\
\hline $2-6$ & -59 & 12 & 96 & -133 & 103 & -34 & -62 & 177 & 15.3 & 0.7 & 5.4 \\
\hline $2-7$ & 176 & -46 & 150 & -137 & 162 & -97 & -152 & 175 & 13.4 & -0.2 & 4.8 \\
\hline $2-8$ & -65 & 153 & 151 & -134 & 126 & -108 & -155 & 171 & 17.1 & -0.4 & 4.6 \\
\hline \multirow[t]{2}{*}{$2-9$} & 175 & -46 & 150 & -141 & 117 & -172 & -87 & -178 & 14.3 & 0.9 & 3.1 \\
\hline & & & & & & & & & & \multicolumn{2}{|c|}{$\Sigma=89.4$} \\
\hline \multicolumn{12}{|c|}{$3\left(\mathrm{D}-\mathrm{Lys} \mathrm{s}^{2}, O r \mathrm{n}^{5}\right)$} \\
\hline $3-1$ & -174 & 154 & 74 & 47 & -161 & 49 & -102 & -50 & 5.4 & 0.0 & 19.2 \\
\hline $3-2$ & 178 & 140 & 152 & -140 & -174 & -153 & -61 & 178 & 15.2 & -2.6 & 14.1 \\
\hline $3-3$ & 177 & 115 & 153 & -168 & 161 & -146 & -62 & 176 & 14.6 & -1.7 & 13.0 \\
\hline $3-4$ & -178 & 158 & 86 & 34 & -124 & -58 & -93 & -60 & 9.9 & 2.1 & 12.6 \\
\hline $3-5$ & -170 & 149 & 82 & -78 & -62 & -40 & -68 & 179 & 9.2 & 3.5 & 11.2 \\
\hline $3-6$ & -172 & -29 & 78 & 27 & -165 & 41 & -73 & -173 & 9.1 & -0.3 & 7.1 \\
\hline $3-7$ & -172 & 147 & 81 & -75 & -76 & 59 & -177 & 165 & 7.9 & -1.1 & 5.5 \\
\hline \multirow[t]{2}{*}{$3-8$} & 179 & 136 & 78 & -147 & 81 & -77 & -55 & 175 & 12.5 & -1.2 & 4.9 \\
\hline & & & & & & & & & & \multicolumn{2}{|c|}{$\Sigma=87.6$} \\
\hline \multicolumn{12}{|c|}{$4\left(\mathrm{D}-\mathrm{Orn}{ }^{2}, \mathrm{Dap}^{5}\right)$} \\
\hline $4-1$ & -176 & 155 & 78 & 39 & -160 & 46 & -142 & -60 & 7.7 & 0.0 & 16.1 \\
\hline $4-2$ & -176 & 156 & 79 & 34 & -139 & 81 & -172 & 165 & 9.5 & 1.5 & 15.6 \\
\hline $4-3$ & -174 & 146 & 73 & 32 & -75 & -32 & -157 & 53 & 9.8 & 2.0 & 9.3 \\
\hline $4-4$ & -174 & 158 & 86 & 41 & -149 & 53 & -140 & -53 & 6.2 & 1.3 & 8.1 \\
\hline $4-5$ & -175 & 155 & 76 & 40 & -159 & 49 & -141 & 40 & 5.4 & 1.2 & 8.1 \\
\hline $4-6$ & -176 & 154 & 71 & 47 & -157 & 45 & -148 & 41 & 5.6 & -0.2 & 8.1 \\
\hline $4-7$ & -177 & 152 & 75 & -162 & 87 & -63 & -56 & 174 & 11.7 & 0.6 & 6.8 \\
\hline $4-8$ & -175 & 154 & 70 & 44 & -152 & 45 & -145 & 41 & 5.5 & 0.9 & 6.8 \\
\hline $4-9$ & 178 & 152 & 86 & -133 & 114 & -41 & -62 & 178 & 12.0 & 2.9 & 5.9 \\
\hline $4-10$ & -176 & 142 & 77 & -152 & 111 & -58 & -64 & -61 & 10.3 & 1.9 & 4.5 \\
\hline $4-11$ & 177 & -44 & 74 & 37 & -147 & 32 & -98 & -56 & 5.3 & 2.5 & 4.5 \\
\hline \multirow[t]{2}{*}{$4-12$} & -176 & 153 & 74 & 54 & -178 & -38 & -53 & 66 & 5.7 & 0.3 & 4.3 \\
\hline & & & & & & & & & & \multicolumn{2}{|c|}{$\Sigma=90.0$} \\
\hline
\end{tabular}

aValues of selected torsional angles for the Tyr-Phe "spacer"; bdistance between tyrosine and phenylalanine ring centers ( $r$ in $\AA)$; crelative calculated energy (E in $\mathrm{kcal} / \mathrm{mol})$; drelative populations of conformers (pop in \%)

terminal segments are directed towards their main ring. These close contacts indicate the presence of additional intramolecular interactions involving aromatic rings and in consequence may have an impact on the possibility of interactions between these rings.

In spite of the differences in distances between the aromatic rings it seems reasonable to assume that these conformations are flexible enough to adopt a conformation permitting interaction with the opioid receptor to induce a biological effect. The similar results for enkephalin-deltorphin hybrids and corresponding enkephalins in the MVD assay support this suggestion.

\section{CONCLUSIONS}

The synthesis of $N$-(ureidoethyl)amides of cyclic enkephalin-deltorphin hybrids was carried out using the method described earlier (Ciszewska et al., 2009). The peptides differed from cyclic enkephalin $N$-(ureidoethyl) amides reported earlier in that the amino acid chain was elongated Cterminally with the Val-Val-Gly sequence, the address sequence of deltorphin responsible for its high affinity for $\delta$ receptors (Charpentier et al., 1991).

It should be noted that the increased selectivity for $\delta$ receptors was mainly result of decreased activity for $\mu$ receptors. The activity in the MVD assay of $N$ ureidoethylamides of cyclic enkephalins and enkephalin-deltorphin hybrids was similar. Since, in most cases, increased selectivity towards $\delta$ receptors was obtained as a result of a decrease of the affinity for $\mu$ receptors, but not an increase towards $\delta$ receptors, it would be reasonable to use the term modulator instead of address for a sequence that changes the receptor selectivity ratio.

St a t is tic a l weights of conformations for three of the six peptides sufficiently soluble in water to permit the recording of NMR spectra were obtained in a global conformational search using the EDMC method in combination with experimental NOE parameters. NOE contacts for all three peptides between their ring protons of Phe 4 and the $\mathrm{CH}_{3}$ groups of $\mathrm{Val}^{6}$ and for peptide 3 between its ring protons of $\mathrm{Tyr}^{1}$ and the $\gamma \mathrm{CH}_{3}$ group of $\mathrm{Val}^{7}$ were observed. This finding indicates that a sequence added to a message, or to a sequence containing the message, is able to introduce additional intra-molecular interactions between the message and the rest of the molecule. In the present studies the additional peptide chain interacting with the message restricted by ring formation had no effect on the results of the MVD assay.

\section{Acknowledgements}

This work was supported by the Ministry of Science and Higher Education, Poland (3T09A 023 28) and the U.S. National Institutes of Health (DA-004443). 


\section{REFERENCES}

Akiyama K, Gee KW, Mosberg HI, Hruby VJ, Yamamura HI (1985) Characterization of $\left[{ }^{3} \mathrm{H}\right][2-\mathrm{D}$-penicillamine, 5-D-penocillamine $]-$ enkephalin binding to $\delta$ opiate receptors in the rat brain and neuroblastoma-glioma hybrid cell line (NG 108-15). Proc Natl Acad Sci USA 82: 2543-2547.

Aue WP, Bartholdi E, Ernst RR (1976) Two-dimensional spectroscopy. Application to nuclear magnetic resonance. J Chem Phys 64: 2229-2246.

Bax A, Davis DG (1985) Practical aspects of two-dimensional transverse NOE spectroscopy. J Magn Reson 63: 207-213.

Bax A, Freeman R (1985) Enhanced NMR resolution by restricting the effective sample volume. J Magn Reson 65: 355-360.

Bothner-By AA, Stephens RL, Lee J-M, Warren CD, Jeanloz RW (1984) Structure determination of tetrasaccharide: transient nuclear Overhauser effects in the rotating frame. I Am Chem Soc 106: 811813.

Braunschweiler L, Ernst RR (1983) Coherence transfer by isotropic mixing: application to proton correlation spectroscopy. J Magn Reson 53: 521-528.

Charpentier S, Sagan S, Delfour A, Nicolas P (1991) Derenkephalin and deltorphin I reveal similarities within ligand-binding domains of $\mu$ - and $\delta$-opioid receptors and an additional address subside on the $\delta$-receptor. Biochem Biophys Res Commun 179: 1161-1168.

Cheng PY, Wu D, Soong Y, McCabe S, Decena JA, Szeto HH (1993) Role of $\mathrm{mu} 1$ - and delta-opioid receptors in modulation of fetal EEG and respiratory activity. Am J Physiol 265: 433-438.

Ciszewska M, Kwasiborska M, Nowakowski M, Oleszczuk M, Wójcik J, Chung NN, Schiller PW, Izdebski J (2009) N-(ureidoethyl)amides of cyclic enkephalin analogs. I Peptide Sci 15: 312-318.

Cohen JH, Abdel-Magid AF, Almond Jr HR, Maryanoff CA (2002) Stereoselective synthesis of beta-aryl-beta-amino esters. Tetrahedron Lett 43: 1977-1981.

Cowan A, Zhu XZ, Mosberg HI, Omnaas JR, Porrwca F (1988) Direct dependence studies in rats with agents selective for different types of opioid receptor. I Pharmacol Exp Ther 246: 950-955.

Davies J (2003) The cyclization of peptides and depsipeptides. J Peptide Sci 9: 471-501.

DiMaio J, Schiller PW (1980) A cyclic enkephalin analog with high in vitro opiate activity. Proc Natl Acad Sci USA 77: 7162-7166.

Filip K, Oleszczuk M, Pawlak D, Wójcik J, Chung NN, Schiller PW, Izdebski J (2003) Potent side-chain to side-chain cyclized dermorphin analogues containing a carbonyl bridge. I Peptide Sci 9: 649657.

Filip K, Oleszczuk M, Wójcik J, Chung NN, Schiller PW, Pawlak D, Zieleniak A, Parcińska A, Witkowska E, Izdebski J (2005) Cyclic enkephalin and endorphin analogues containing a carbonyl bridge. $J$ Peptide Sci 11: 347-352.

Gutkowska J, Jankowski M, Pawlak D, Makaddam-Daher S, Izdebski J (2004) The cardiovascular and renal effects of highly potent $\mu$-opioid receptor agonist, cyclo $\left[\mathrm{N}^{\S}, \mathrm{N}^{\beta}\right.$-carbonyl-D-Lys $\left.{ }^{2}, \mathrm{Dap}^{5}\right]$ enkephalinamide. Eur J Pharmacol 496: 167-174.

Hendrson G, Hughes J, Kosterlitz H (1972) A new example of morphine sensitive neuroeffector junction. Br J Pharmacol 46: 764-766.

Humphrey W, Dalke A, Schulten K (1996) VMD — visual molecular dynamics. I Mol Graphics 14: 33-38.

Janecka A, Kruszynski R (2005) Conformationally restricted peptides as tools in opioid receptor studies. Curr Med Chem 12: 471-481.

Kay LE, Keifer P, Saarinen T (1992) Pure absorption gradient-enhanced heteronuclear single quantum correlation spectroscopy with improved sensitivity. J Am Chem Soc 114: 10663-10665.

Kotlińska J, Bochenski M, Lagowska-Lenard M, Gibula-Bruzda E, Witkowska E, Izdebski J (2009) Enkephalin derivative, cyclo[N $\mathrm{N}^{\beta}$ -carbonyl-D-Lys ${ }^{2}$, Dap 5 enkephalinamide (CUENK6), induces a highly potent antinociception in rats. Neuropeptides 43: 221-228.

Li Z, Scheraga HA (1987) Monte Carlo-minimization approach to the multiple-minima problem in protein folding. Proc Natl Acad Sci USA 84: 6611-6615.
Liwo A, Tempczyk A, Oldziej S, Shenderowicz MD, Hruby VJ, Talluri S, Ciarkowski J, Kasprzykowski F, Lankiewicz L, Grzonka Z (1996) Exploration of conformational space of oxytocin and arginine-vasopressin using the electrostatically driven Monte Carlo and Molecular Dynamics methods. Biopolymers 38: 157-175.

Marquardt DW (1963) An algorithm for least-squares estimation of nonlinear parameters. I Soc Indust Appl Math 11: 431-441.

Masman MF, Rodriguez AM, Svetaz L, Zacchino SA, Somlai C, Csizmadia IG, Penke B, Enriza RD (2006) Synthesis and conformational analysis of His-Phe-Arg-Trp- $\mathrm{NH}_{2}$ and analogues with antifungal properties. Bioorgan Med Chem 14: 7604-7614.

Masman MP, Somlai C, Garibotto FM, Rodriguez AM, de la Iglesia A, Zacchino SA, Penke B, Enriza RD (2008) Structure-antifungal relationship of His-Phe-Arg-Trp-Gly-Lys-Pro-Val-NH $\mathrm{N}_{2}$ and analogues. Bioorgan Med Chem 16: 4347-4358.

Meadows RP, Post CB, Luxon BA, Gorenstein DG (1994) MORASS 2.1. W. Lafayette Pardue University.

Misicka A, Lipkowski A, Horvath R, Davis P, Porreca F, Yamamura HI, Hruby VJ. (1994) Int J Peptide Protein Res 44, 80-84.

Nemethy G, Gibson KD, Palmer KA, Yoon CN, Paterlini G, Zagari A, Rumsey S, Sheraga HA (1992) Energy parameters in polypeptides. 10. Improved geometrical parameters and nonbonded interactions for use in the ECEPP/3 algoritm, with application to pralinecontaining peptides. J Phys Chem 96: 6472-6484.

Palmer III AG, Cavanagh J, Wright PE, Rance M (1991) Sensitivity improvement in proton detected heteronuclear correlation experiments. J Magn Reson 93: 151-170.

Paton WDM (1957) The action of morphine and related substances on contraction on acylcholine output of coaxially stimulated guinea pig ileum. Br J Pharmacol 12: 119-127.

Pawlak D, Chung NN, Schiller PW, Izdebski J (1997) Synthesis of novel side-chain to side-chain cyclized enkephalin analogues containing a carbonyl bridge. J Peptide Sci 3: 277-281.

Pawlak D, Oleszczuk M, Wójcik J, Pachulska M, Chung NN, Schiller PW, Izdebski J (2001) Highly potent side chain to side chain cyclized enkephalin analogs containing a carbonyl bridge: synthesis, biology and conformation. J Peptide Sci 7: 128-140.

Su YF, McNutt RW, Chung KJ (1998) Delta-opioid ligands reverse alfentanil-induced respiratory depression but not antinociception. $J$ Pharmacol Exp Ther 287: 815-823.

Schiller PW, Lipton A, Horrobin DF, Bodanszky M (1978) Unsulfated C-terminal 7-peptide of cholecystokinin: a new ligant of the opiate receptor. Biochem Biophys Res Commun 85: 1332-1338.

Sidor M, Wójcik J, Pawlak D, Izdebski J (1999) Conformational analysis of novel cyclic enkephalin analogue using NMR and EDMC calculations. Acta Biochim Pol 46: 641-650.

Spath H (1980) Cluster Analysis Algorithms. Halsted Press, New York.

Vila J, Wiliams RI, Vasquez M, Scheraga HA (1991) Empirical salvation models can be used to differentiate native from near-native conformations of bovine pancreatic trypsin inhibitor. Proteins: Struct Funct Genet 10: 199-218.

Waterfield AA, Leslie FM, Lord JAH, Ling N (1979) Opioid activities of fragments of $\beta$-endorphin and of its leucine ${ }^{65}$-analogue 5 . Eur J Pharmacol 58: 11-18.

Wishart DS, Bigam CG, Yao J, Abildgaard F, Dyson HJ, Oldfield E, Markley JL, Sykes BDl $(1995){ }^{1} \mathrm{H},{ }^{13} \mathrm{C},{ }^{15} \mathrm{~N}$ chemical shift referencing in biomolecular NMR. J Biomol NMR 6: 135-140.

Wiszniewska A, Kunce D, Chung NN, Schiller PW, Izdebski J (2005) p-Nitrophenoxycarbonyl derivatives of Boc-protected diaminoalkanes in the synthesis of enkephalin peptidomimetics. I Peptide Sci 11: $579-583$.

www.cgl.ucaf.edu/home/sparky

www.actabp.pl/Paper in Press

Zieleniak A, Rodziewicz-Motowidło S, Rusak Ł, Chumg NN, Czaplewski C, Witkowska E, Schiller PW, Ciarkowski J, Izdebski J (2008) Deltorphin analogs restricted via a urea structure and opioid activity. J Peptide Sci 14: 830-837.

Supplementary Materials available at: www.actabp.pl 